\title{
PENGARUH METODE PEMASAKAN TERHADAP NILAI SENSORI DAN PROFIL ASAM AMINO CAKALANG (Katsuwonus pelamis) MASAK
}

\section{THE EFFECT OF COOKING METHODS ON SENSORY AND AMINO ACID PROFILES OF COOKED SKIPJACK TUNA (Katsuwonus pelamis)}

\author{
I Ketut Sumandiarsa ${ }^{1 \#}$, Resmi R. Siregar ${ }^{1}$, Kadek Ayu Sastra Dewi ${ }^{2}$ \\ ${ }^{1}$ Politeknik Ahli Usaha Perikanan \\ Jl. AUP Pasar Minggu, Jakarta Selatan \\ ${ }^{2}$ PT. Bintang Jayakota Mandiri. Benoa, Bali \\ E-mail: ketut.andistp@gmail.com
}

(Diterima: 15 Juni 2020; Diterima setelah perbaikan: 14 Desember 2020; Disetujui: 14 Desember 2020)

\begin{abstract}
ABSTRAK
Asam amino merupakan suatu zat penyusun protein yang saling berikatan membentuk ikatan peptida. Jumlah asam amino setelah pemasakan akan mempengaruhi sifat dan kandungan kimia produk. Penelitian ini bertujuan untuk mengetahui pengaruh metode pemasakan terhadap nilai sensori dan profil asam amino pada cakalang masak. Cara pemasakan dibedakan atas Kukus, Presto dan Steam precooked yang menggunakan suhu dan waktu yang sama yaitu $100^{\circ} \mathrm{C}$ selama 45 menit. Rancangan penelitian menggunakan rancangan acak lengkap (RAL) satu faktor terhadap perlakuan cara pemasakan dan selanjutnya menggunakan analisis keragaman (ANOVA) uji lanjut dengan uji Duncan serta uji Kruskal Wallis terhadap kesukaan. Hasil penelitian menyatakan panelis lebih menyukai cakalang presto dengan nilai rata-rata kenampakan $7.1 \pm 0.94$; bau $7.4 \pm 0.71$; dan tekstur $7.2 \pm 0.96$. Hasil uji sensori menunjukkan yang terbaik adalah cakalang presto dengan nilai rata-rata kenampakan $7.4 \pm 1.1$; bau $8.7 \pm 0.05$ dan tekstur $8.1 \pm 0.17$. Asam amino cakalang segar menunjukkan asam glutamate merupakan yang terbesar yaitu $3.16 \%$ dan terkecil adalah Serin sebesar $0.51 \%$ dengan total asam amino adalah $20.30 \%$. Berdasarkan cara memasak, asam amino tertinggi terdapat pada Kukus yang diikuti oleh Presto dan Steam cooked dengan masing-masing 24.85\%; $24.10 \%$; dan 21.01\%. Cara pemasakan tidak berpengaruh nyata terhadap kuantitas asam amino namun karakteristik bau dan tekstur secara signifikan dipengaruhi oleh cara masak yang berbeda $(\operatorname{Sig}(0.000)<(a ́=0.05))$.
\end{abstract}

KATA KUNCI: Ikan Cakalang; metode pemasakan; asam amino

\begin{abstract}
The amino acid is a constituent of proteins that bind together to form peptide bonds. The number of amino acids after cooking will affect the nature and chemical content of the products. This study was aimed to determine the effect of cooking methods on sensory values and amino acid profiles in cooked Tuna. Cooking methods are divided into regular Steam, Presto and Steam precooked at the same temperature and time of $100^{\circ} \mathrm{C}$ for 45 minutes. Completely randomized design of one factor was employed, and Analyse of variance (ANOVA) was used to analyze the effect of method and followed by Duncan posthoc analysis. On the other hand, a Kruskal Wallis test is used to determine the preferences of the panellist. The results stated that the Presto method is the best for the hedonic test with a value of appearance, odour and texture about $7.1 \pm 0.94 ; 7.4 \pm 0.71$ and $7.2 \pm 0.96$ respectively. In the same case, based on a sensory test of final products, Presto was also the finest with an average appearance of $7.4 \pm 1.1$; the smell of $8.7 \pm$ 0.05 and texture of $8.1 \pm 0.17$. The fresh skipjack amino acid analysis showed that glutamate acid was the biggest at $3.16 \%$, and the smallest was Serin at $0.51 \%$ with a total amino acid of $20.30 \%$. Based on cooking methods, the highest amino acids were found in normal Steamed, followed by Presto and Steam cooked
\end{abstract}

\# Korespondensi: Politeknik Ahli Usaha Perikanan

E-mail: ketutandistp@gmail.com 
with 24.85\%; 24.10\%; and 21.01\% correspondingly. The cooking method does not significantly affect the number of amino acids, but the odour and texture characteristics were significantly influenced by different cooking methods (Sig (0.000) < (á = 0.05)).

KEYWORDS: Skipjack; cooking methods; amino acid

\section{PENDAHULUAN}

Ikan sebagai bahan pangan konsumsi telah meningkat baik secara produksi maupun jumlah konsumsi oleh masyarakat dunia termasuk di negara maju seperti Eropa (Sotelo CG et al., 2018). Tahun 2016 dilaporkan bahwa produksi ikan meningkat 3.2\% sedangkan konsumsi dunia terkini adalah $20.5 \mathrm{~kg}$ perkapita. Hal tersebut didukung oleh produksi perikanan tangkap sebesar 90.9 juta ton pada tahun 2016. Salah satu komoditas penting dari produksi perikanan tangkap adalah ikan Cakalang/ Skipjack tuna/ Katsuwonus pelamis sebesar 2,829,929 ton (FAO, 2018).

Ikan cakalang merupakan salah satu jenis ikan tuna yang sering diolah menjadi berbagai jenis produk perikanan beku (loin, steak, cakalang precooked dan produk dalam kaleng) (Yunindra, 2014; Miao et al., 2017)). Ikan merupakan sumber protein yang tinggi secara umum kadarnya 18 - $20 \%$ (Suwetja, 2011). Protein ikan sangat diperlukan oleh manusia karena selain mudah dicerna juga mengandung berbagai jenis asam amino esensial maupun non esensial yang bermanfaat bagi kesehatan di mana daging putih pada ikan scromboid (seperti tongkol dan sejenisnya) mengandung lebih banyak protein yaitu sebesar $68.36 \%$ berat kering (Hafiludin, 2011). Mutu protein dapat dinilai dari susunan dan perbandingan asam amino yang terkandung dalam protein tersebut. Prinsipnya suatu protein harus mampu menyediakan asam - asam amino esensial dalam suatu perbandingan yang menyamai kebutuhan manusia mempunyai mutu yang tinggi (Winarno, 2004).

Proses pengolahan dengan menggunakan suhu tinggi rentan terhadap penurunan mutu dan nilai gizi pangan. Seperti disebutkan oleh Sundari, et al. (2015) bahwa pengolahan bahan pangan dengan menggunakan proses pemasakan umumnya mengakibatkan penurunan komposisi kimia dan zat gizi pangan. Pengolahan dengan suhu tinggi menyebabkan protein terdegradasi. Hal ini terjadi misalnya pada suhu $115^{\circ} \mathrm{C}$ di dalam retort. Asam amino sistein akan berkurang $10 \%$ jika dipanaskan selama 20 menit pada suhu $115^{\circ} \mathrm{C}$ (Suwetja, 2011). Pengolahan yang secara signifikan merusak atau mendegradasi protein pada ikan adalah proses penggorengan (frying) yang selanjutnya diikuti oleh proses pengeringan dan pemangganggan (SteinerAsiedu et al., 1991; Ayinsa \& Maalekuu, 2013; Deng et al., 2015). Oleh karena itu, tujuan dari penelitian ini adalah untuk mengetahui mutu ikan cakalang masak berupa nilai sensori dan profil asam amino yang diolah melalui tiga cara yang berbeda yaitu Kukus, Presto dan Steam precooked.

\section{METODE}

\section{Bahan dan Alat}

Bahan baku yang digunakan pada penelitian ini adalah ikan cakalang (Katsuwonus pelamis) beku yang diperoleh dari PT. Karya Mandiri Citramina, Muara Baru Jakarta. Alat yang digunakan berupa pisau stainless steel, termometer, baskom, meja kerja, timbangan (Vibra), pan stainless steel, steam cooker (GETRA NFC CONVECTION OVEN), alat presto, panci pengukus dan kompor. Alat yang digunakan untuk pengujian asam amino adalah perangkat HPLC (High Performace Liquid Chromatography) ICI Instrument/SHIMADZU SCL - 10A/ SHIMADZU CBM 20A, oven (Memmert), sryringe $100 \mu \mathrm{l}$, vial $1 \mathrm{ml}$, neraca analitik (Vibra), pipet $1 \mathrm{ml}$ (Pyrex), labu takar $100 \mathrm{ml}$ (Boral Pula), tabung ulir (Uario), kertas membran millipore 0.45 mikron (Sartorius Stedim) dan rotary evaporator (Buchi Rotavapor R.3).

\section{Metode penelitian}

\section{Pengolahan cakalang masak}

Proses pengolahan cakalang masak dilakukan mengacu pada SNI tuna loin masak beku 7968:2014. Adapun alur proses pengolahan cakalang masak terdiri dari bahan baku, pelelehan, penyiangan, pencucian, pemasakan, pendinginan, pemisahan kepala dan ekor, pengulitan dan pembersihan daging. Proses pemasakan menggunakan suhu dan waktu yang sama yaitu $100^{\circ} \mathrm{C}$ selama 45 menit. Seluruh tahapan proses pengolahan dilakukan berdasarkan prinsip-prinsip pengolahan yang baik dan benar serta memperhatikan aspek-aspek sanitasi dan hygiene.

\section{Karakteristik bahan baku}

Penentuan karakteristik bahan baku ikan cakalang yang digunakan dalam penelitian meliputi pengujian organoleptik ikan cakalang keadaan beku dan setelah thawing, serta pengujian profil asam amino sebagai bahan baku. Pengujian organoleptik dilakukan terhadap bahan baku dalam keadaan beku dengan parameter 
berupa lapisan es, dehidrasi dan diskolorisasi sedangkan bahan baku setelah thawing dengan parameter meliputi kenampakan, bau dan daging.

\section{Karakteristik produk akhir}

Produk akhir berbentuk loin masak beku dikarakterisasi melalui pengujian sensori dan hedonik oleh panelis terlatih yang selanjutnya dilakukan pengujian profil asam amino yang terdiri dari 15 profil baik esensial maupun non esensial. Alat yang digunakan untuk pengujian asam amino adalah perangkat HPLC (High Performace Liquid Chromatography) ICI Instrument/SHIMADZU SCL-10A/SHIMADZU CBM 20A, oven (Memmert), sryringe $100 \mu \mathrm{l}$, vial $1 \mathrm{ml}$, neraca analitik (Vibra), pipet $1 \mathrm{ml}$ (Pyrex), labu takar $100 \mathrm{ml}$ (Boral Pula), tabung ulir (Uario), kertas membran millipore 0.45 mikron (Sartorius Stedim) dan rotary evaporator (Buchi Rotavapor R.3).

\section{Rancangan Penelitian dan Analisis Data}

Rancangan penelitian ini menggunakan rancangan acak lengkap (RAL) satu faktor yang terdiri dari 3 perlakuan yaitu pengukusan, presto dan steam precooked. Masing-masing perlakuan terdiri dari 3 kali ulangan. Data dianalisis keragamannya (ANOVA), dan apabila hasilnya menunjukkan ada beda nyata, maka dilanjutkan dengan uji Duncan. Selanjutnya, analisis data uji kesukaan dilakukan menggunakan Kruskal Wallis. Semua data diolah dengan menggunakan aplikasi SPSS versi 24.

\section{HASIL DAN PEMBAHASAN}

\section{Karakteristik bahan baku}

Hasil pengujian organoleptik nilai bahan baku menunjukkan bahwa bahan baku masih memiliki mutu yang baik yaitu $7.5-8.0$. Nilai organoleptik ikan cakalang sudah memenuhi persyaratan sesuai dengan SNI 01-4110.1-2006. Hasil pengujian organoleptik bahan baku ikan cakalang dapat dilihat pada Tabel 1 . Tinggi rendahnya mutu bahan baku dipengaruhi oleh berbagai faktor, salah satunya adalah cara penanganan seperti penerapan suhu dingin di seluruh rantai pasok di mana suhu rendah dapat mempertahankan mutu cakalang segar hingga 10 hari penyimpanan (Ekasari et al., 2017). Menurut (Alexi et al., 2017), sensori terhadap tekstur paling signifikan mempengaruhi pemilihan konsumen terhadap produk ikan segar dibandingkan dengan aroma.

Tingkat kesegaran bahan baku akan berpengaruh pada mutu produk akhir yang dihasilkan karena karakteristik mutu seperti kandungan histamine erat

Tabel 1. Nilai organoleptik bahan baku ikan cakalang

Table 1. Organoleptic value of Skipjack as raw material

\begin{tabular}{|c|c|c|c|c|c|c|}
\hline Ulangan & $\begin{array}{c}\text { Dalam Keadaan } \\
\text { Beku }\end{array}$ & Nilai & SNI & $\begin{array}{c}\text { Sesudah } \\
\text { dilelehkan }\end{array}$ & Nilai & SNI \\
\hline 1 & $7.73<\mu<8.26$ & 8.0 & \multirow{3}{*}{7.0} & $7.48<\mu<7.84$ & 7.5 & \multirow{3}{*}{7.0} \\
\hline 2 & $7.53<\mu<8.24$ & 7.5 & & $7.65<\mu<8.13$ & 8.0 & \\
\hline 3 & $7.73<\mu<8.26$ & 8.0 & & $7.48<\mu<8.07$ & 7.5 & \\
\hline
\end{tabular}

\#

kaitannya dengan kondisi bahan baku (Miao et al., 2017).

Analisis asam amino telah dilakukan untuk mengetahui profil dan kandungan asam amino yang terkandung dalam daging ikan cakalang segar. Berdasarkan hasil pengujian asam amino pada ikan cakalang segar terdapat 15 jenis asam amino yang terdiri dari 8 macam asam amino esensial (histidin $1.87 \%$, lisin $1.73 \%$, leusin $1.72 \%$, valin $1.31 \%$, isoleusin $1.14 \%$, treonin $0.97 \%$, fenilalanin $0.88 \%$, dan metionin $0.64 \%$ ) dan 7 macam asam amino non esensial (glutamat $3.16 \%$, aspartat $2.05 \%$, alanin $1.27 \%$, arginin $1.27 \%$, glisin $1.11 \%$, tirosin $0.67 \%$, dan serin $0.51 \%$ ). Hasil ini tidak berbeda jauh dengan profil asam amino dari penelitian Erkan, Ozden, \& Selcuk, (2010) terhadap beberapa jenis ikan laut segar. Di sisi lain, proses pelelehan/ thawing telah secara signifikan mempengaruhi mutu secara mikrobiologi berupa meningkatnya jumlah mikroba pada bahan baku
(Hosseini \& Abdolmaleki, 2017). Asam amino esensial adalah asam amino yang tidak dapat disintesis dalam tubuh manusia, melainkan dapat diperoleh dari sumber makanan manusia. Asam amino non esensial adalah asam amino yang dapat disintesis dalam tubuh manusia (Sediaoetama, 2000). Adapun grafik hasil pengujian asam amino pada ikan cakalang segar dapat dilihat pada Gambar 1.

Asam amino esensial tertinggi yaitu histidin sebesar $1.87 \%$. Hal tersebut karena ikan cakalang merupakan salah satu ikan tuna di mana keluarga ikan tuna atau scombroidae memiliki kandungan histidin bebas (free histidin) yang tinggi. Asam amino non esensial tertinggi adalah glutamat sebesar $3.16 \%$ per 100 gr daging.

Mutu protein tergantung dari kelengkapan kadar asam amino esensialnya. Protein hewani termasuk hasil perikanan mempunyai nilai biologi protein yang 
tinggi sebagai sumber asam amino esensial (Nurjanah et al., 2011). Ikan tuna memiliki kandungan glutamat yang tinggi sehingga seringkali daging ikan kayu atau katsuobushi diolah menjadi bahan penyedap masakan atau monosodium glutamat atau lebih dikenal dengan MSG. Asam glutamat sangat penting peranannya dalam pengolahan makanan, karena dapat menimbulkan rasa lezat, dalam bumbu masak yang mengandung monosodium glutamat, gugusan glutamat akan bergabung dengan senyawa lain menghasilkan rasa enak (Winarno, 2004).

Fungsi utama asam amino adalah sintesa protein dan produksi energi serta fungsi khusus terdapat pada masing-masing jenis. Seperti halnya fungsi Histidin sebagai precursor histamin dalam rangka pertumbuhan, Lisin sebagai cross-linking prosess biosintesis protein. Valin berperan dalam pertumbuhan, sistem saraf dan pencernaan. Isoleusin berperan dalam pembentukan otot dan haemoglobin sedangkan Treonin berperan dalam mempertahankan keseimbangan protein, berperan dalam pembentukan kolagen dan elastin. Selain itu, Fenilalanin berfungsi sebagai precursor tirosin, katekolamin dan melanin sedangkan Metionin berfungsi sebagai precursor sistein. Asam amino glutamate yang tertinggi pada ikan cakalang segar memiliki peran dalam reaksi transaminase (Linder, 2006; Yuliarti, 2009; Mohanty et al., 2014).

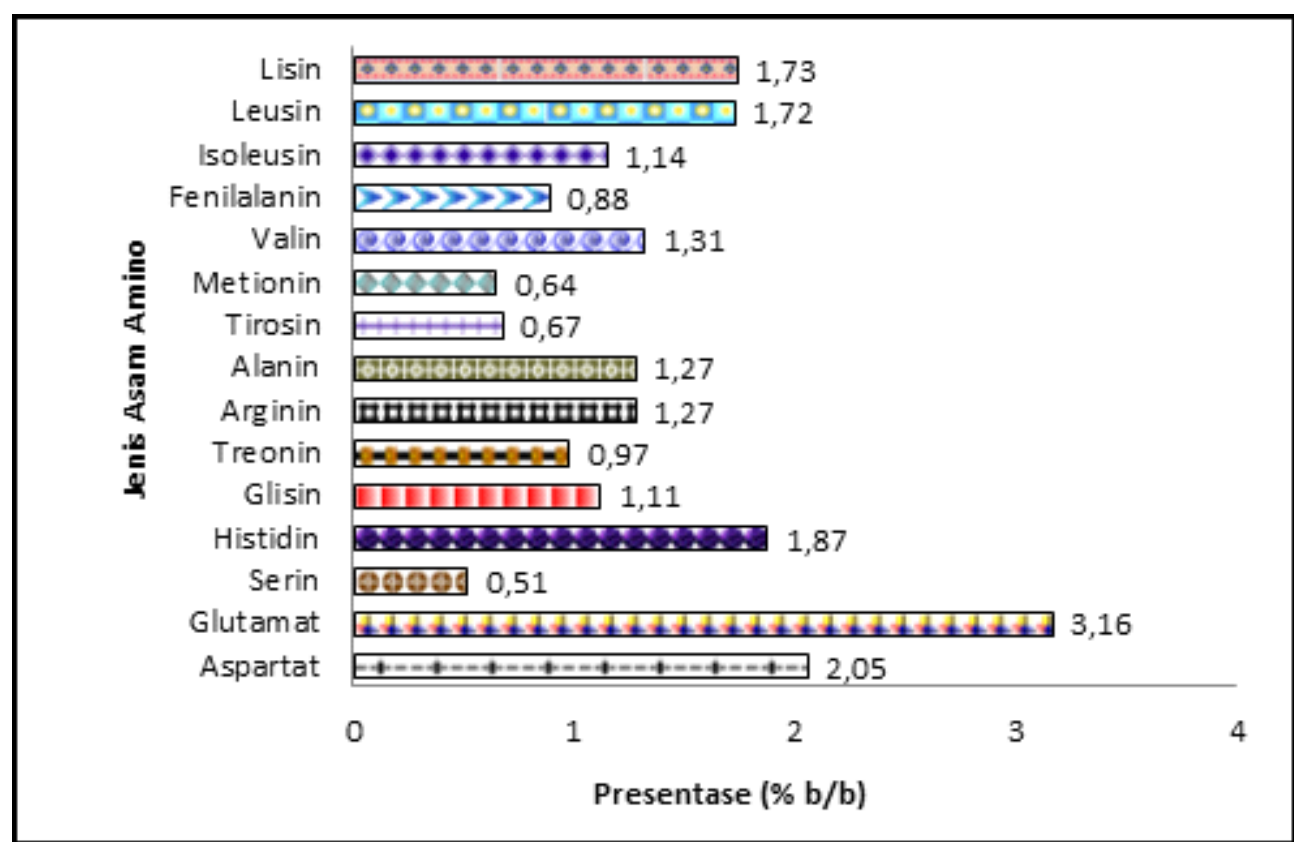

Gambar 1. Profil dan Kandungan Asam Amino esensial dan non esensial pada Ikan Cakalang Segar (Kotak kuning =esensial; kotak merah $=$ non-esensial)

Figure 1. Essential and non-essential of amino acid profile and content of fresh Skipjack (Yellow box=essential; red box $=$ non-essential)

\section{Karakteristik produk Cakalang masak}

\section{Hedonik}

Berdasarkan parameter dari produk yang diuji, nilai hedonik ikan cakalang masak dapat dilihat pada Tabel 2.Berdasarkan hasil uji hedonik diketahui bahwa tingkat penerimaan panelis terhadap ikan cakalang masak secara umum dapat diterima oleh panelis. Nilai rata-rata kenampakan pada metode masak kukus, presto dan steam precooked adalah 6.7, 7.1 dan 6.6, dengan taraf asymp. Sig $(0.116)>(a ́=0.05)$ menunjukkan bahwa metode masak tidak berpengaruh nyata terhadap kenampakan. Nilai rata-rata bau pada metode masak kukus, presto dan steam precooked adalah 6.8, 7.4 dan 6.2 dengan taraf asymp. Sig (0.000) $<$ (á $=0.05)$ menunjukkan bahwa metode masak berpengaruh nyata terhadap bau cakalang. Bau cakalang steam precooked, presto dan kukus berbeda nyata satu sama lain. Nilai rata-rata tekstur pada metode masak kukus kovensional, presto dan steam precooked adalah 6.8, 7.2 dan 6.4 dengan taraf asymp. Sig $(0.003)<(a ́=0.05)$ menunjukkan bahwa metode masak berpengaruh nyata terhadap tekstur. Parameter tekstur sangat penting karena mempengaruhi hedonik konsumen dan lebih dipertimbangkan daripada bau/ aroma (Alexi et al., 2017). Tekstur terbentuk akibat penerapan waktu dan suhu saat proses pengolahan 
(Mugale et al., 2018). Tingkat kesukaan dapat pula dipengaruhi oleh cara perendaman bahan baku sebelum diproses karena proses tersebut secara nyata dapat meningkatkan tekstur, bau dan juga rasa (Bulele et al., 2017).

\section{Sensori}

Ikan cakalang masak (kukus, presto, steam precooked) diuji sensori menggunakan score sheet tuna loin masak beku (SNI 7968:2014) yang meliputi kenampakan, bau dan tekstur. Hasil uji sensori menunjukan bahwa rata - rata menunjukan nilai sensori untuk cakalang kukus, presto dan steam precooked menghasilkan nilai rata-rata yaitu 7.7, 8.1 dan 7.4. Nilai sensori ikan cakalang masak ketiga metode pemasakan dapat dilihat pada Tabel 3.
Nilai sensori produk akhir suatu produk tidak terlepas dari mutu bahan baku yang digunakan dan proses pengolahan yang baik dan benar seperti pada produk-produk berbasis tuna seperti cooked steak tuna (Miao.H et al., 2017). Berdasarkan hasil pengujian dapat diketahui bahwa cakalang presto mendapat ratarata nilai tertinggi pada parameter kenampakan, bau dan tekstur sehingga dapat disimpulkan bahwa preferensi panelis terhadap produk berdasarkan parameter cara pemasakan tersebut adalah cakalang yang dimasak dengan metode presto. Parameter bau/ aroma mungkin dipengaruhi oleh adanya senyawasenyawa aromatik yang terbentuk pada saat proses pemanasan berlangsung seperti 3-hydroxybutan-2-one, Octanal, nonanal, 2-pentylfuran, 1-octen-3-ol, hexanal, dan 2-ethyl-furan terdeteksi dominan pada ikan tuna masak (Salum et al., 2017; Zhang et al., 2019).

Tabel 2. Nilai hedonik ikan cakalang masak

Table 2. Hedonic value of cooked Skipjack

\begin{tabular}{lccc}
\hline \multicolumn{1}{c}{ Pemasakan } & Kenampakan & Bau & Tekstur \\
\hline Kukus & $6.7 \pm 0.87$ & $6.8 \pm 0.96^{\mathrm{b}}$ & $6.8 \pm 0.81^{\mathrm{ab}}$ \\
Presto & $7.1 \pm 0.94$ & $7.4 \pm 0.71^{\mathrm{c}}$ & $7.2 \pm 0.96^{\mathrm{b}}$ \\
Steam precooked & $6.6 \pm 1.04$ & $6.2 \pm 1.01^{\mathrm{a}}$ & $6.4 \pm 0.88^{\mathrm{a}}$ \\
\hline
\end{tabular}

\#

Tabel 3. Nilai sensori ikan cakalang masak

Table 3. Sensory value of cooked Skipjack

\begin{tabular}{lcccc}
\hline \multicolumn{1}{c}{ Pemasakan } & Kenampakan & Bau & Tekstur & SNI \\
\hline Kukus & $7.8 \pm 0.4$ & $7.9 \pm 0.85$ & $7.4 \pm 0.23$ & \\
Presto & $7.4 \pm 1.1$ & $8.7 \pm 0.05$ & $8.1 \pm 0.17$ & Min 7.0 \\
Steam precooked & $7.9 \pm 0.72$ & $7.2 \pm 0.5$ & $7.1 \pm 0.51$ & \\
\hline
\end{tabular}

\#

\section{Profil asam amino}

Terdapat 15 jenis asam amino yang terkandung pada daging ikan cakalang segar, kukus, presto dan steam precooked. Profil dan kandungan asam amino cakalang segar dan cakalang masak dapat dilihat pada Tabel 4 .

Daging ikan cakalang segar pada umumnya mengandung protein sebesar $\pm 25 \%$ protein dan juga 1-2\% lemak (Nurjanah et al., 2015). Daging putih mengandung lebih banyak protein dibanding dengan daging merah $(68.36 \%$ : 31.64\%) (Hafiludin, 2011). Sedangkan untuk produk beku, protein yang terkandung yang pernah dilaporkan sebesar $24.6 \mathrm{~g} /$ $100 \mathrm{~g}$ (Kim et al., 2019). Terdapat perbedaan jumlah asam amino antara bahan baku segar dan beku dipengaruhi oleh proses pelelehan/thawing karena protein yang larut dalam air terlarut ketika di-thawing (Hosseini \& Abdolmaleki, 2017).

Berdasarkan hasil pengujian, perbandingan hasil uji asam amino ikan segar sangat berbeda setelah dilakukan proses pemasakan. Hasil analisis statistik ANOVA F hitung (3.989) < F tabel (5.143) dengan tingkat kepercayaan 95\% maka metode pemasakan tidak memberikan pengaruh terhadap kandungan asam amino cakalang masak atau bahwa perlakuan metode masak tidak berbeda nyata terhadap kandungan asam amino. Perlakukan suhu dan lama waktu pemasakan yang sama mungkin menjadi faktor utama sehingga profil asam amino tidak berbeda satu sama lain walaupun dalam beberapa penelitian disebutkan bahwa tinggi rendahnya komposisi asam amino baik esensial maupun non esensial dipengaruhi oleh metode pemasakan baik itu melalui proses pengeringan, penggorengan, perebusan, dan pengukusan (SteinerAsiedu et al., 1991; Erkan et al., 2010; Deng et al., 2015). Hasil profiling menunjukkan bahwa pemasakan dengan cara pengukusan memiliki kandungan asam amino terbesar secara persentasi dibanding dengan metode lainnya. Cakalang segar mengandung presentasi yang tinggi hal ini dapat dilihat dan 
dibandingkan dengan hasil penelitian lain seperti oleh Nurjanah et al., (2015), melaporkan bahwa profil asam amino pada Cakalang segar sebesar $74.25 \mathrm{~g} / 100 \mathrm{~g}$ produk kering dengan komposisi asam amino yang hampir sama dan asam glutamate yang mendominasi seperti pada hasil penelitian ini. Perubahan asam amino dan kandungan proksimat secara signifikan dipengaruhi oleh metode pemasakan. Berdasarkan hasil penelitian (Erkan et al., 2010), protein beberapa jenis ikan mengalami peningkatan setelah dimasak seperti Atlantic bonito yaitu digoreng, dipanggang dan dikukus dari $11 \%$ menjadi masing-masing 19\%, $23 \%$, dan $18 \%$. Artinya, proses tersebut tidak merusak protein sehingga sangat layak direkomendasikan sebagai cara mengolah ikan untuk konsumsi. Namun demikian, terjadi perubahan struktur secara nyata pada myosin, profil asam amino dan kemampuan cerna akibat pemanasan (Deng et al., 2015).

\section{KESIMPULAN}

Berdasarkan uji Hedonik dan Sensori, produk cakalang presto merupakan produk yang terbaik dari 2 metode lainnya. Namun demikian, metode pemasakan tidak berpengaruh nyata terhadap karakteristik kenampakan, tetapi berpengaruh nyata pada bau dan tekstur cakalang masak. Metode kukus merupakan metode pengolahan terbaik bila dibandingkan dengan metode presto dan steam precooked jika dilihat dari persentase kandungan asam amino baik esensial mapun non esensial tetapi secara statistik 3 metode pemasakan dalam penelitian ini tidak berpengaruh nyata terhadap persentase komposisi asam amino di mana F hitung (3.989) $<$ F tabel (5.143).

Tabel 4. Kandungan asam amino total cakalang segar dan cakalang masak (kukus, presto, steam precooked). Table 4. Total amino acid content of fresh and cooked Skipjack (steam, presto, steam cooked)

\begin{tabular}{llcccc}
\hline No & Asam Amino & \multicolumn{3}{c}{ Hasil $\begin{array}{c}\text { \% } \\
\text { Sram asam amino/100 gram } \\
\text { cakalang) }\end{array}$} \\
& & Segar & Kukus & Presto & $\begin{array}{c}\text { steam } \\
\text { precooked }\end{array}$ \\
\hline 1 & Aspartat & 2.05 & 2.50 & 2.49 & 2.12 \\
2 & Glutamat & 3.16 & 3.60 & 3.62 & 3.09 \\
3 & Serin & 0.51 & 0.84 & 0.81 & 0.65 \\
4 & Histidin* & 1.87 & 2.16 & 2.04 & 2.10 \\
5 & Glisin & 1.11 & 1.35 & 1.23 & 1.20 \\
6 & Treonin* & 0.97 & 1.20 & 1.17 & 0.92 \\
7 & Arginin* & 1.27 & 1.61 & 1.49 & 1.25 \\
8 & Alanin & 1.27 & 1.50 & 1.47 & 1.27 \\
9 & Tirosin & 0.67 & 0.82 & 0.81 & 0.68 \\
10 & Metionin* & 0.64 & 0.71 & 0.76 & 0.65 \\
11 & Valin* & 1.31 & 1.53 & 1.52 & 1.30 \\
12 & Fenilalanin* & 0.88 & 1.07 & 1.04 & 0.88 \\
13 & Isoleusin* & 1.14 & 1.37 & 1.33 & 1.15 \\
14 & Leusin* & 1.72 & 2.04 & 2.02 & 1.72 \\
15 & Lisin* & 1.73 & 2.55 & 2.29 & 1.77 \\
& Total (\%) & $\mathbf{2 0 . 3 0}$ & $\mathbf{2 4 . 8 5}$ & $\mathbf{2 4 . 1 0}$ & $\mathbf{2 1 . 0 1}$ \\
\hline
\end{tabular}

\section{DAFTAR PUSTAKA}

Alexi, N., Byrne, D. V, Nanou, E., Grigorakis, K., Perception, F. Q., Hellinikon, A. K., \& Perception, F. Q. (2017). Investigation of sensory profiles and hedonic drivers of emerging aquaculture fish species. Journal of the Science of Food and Agriculture, 93(3).

Badan Standarisasi Nasional. (2014). Tuna Loin Masak
Beku. SNI 7968:2014. BSN. Jakarta.

Bulele, A. Y., Pongoh, J., \& Reo. A.R. (2017). Tingkat Kesukaan Konsumen Terhadap Ikan Cakalang ( Katsuwonus pelamis L .) Asap Yang Direndam Dalam Ekstrak Kulit Manggis. Jurnal Media Teknologi Hasil Perikanan, 5(1), 19-23.

Deng, Y., Luo, Y., Wang, Y., \& Zhao, Y. (2015). Effect of different drying methods on the myosin structure, amino acid composition , protein digestibility and 
volatile profile of squid fillets. FOOD CHEMISTRY, 171, 168-176. https://doi.org/10.1016/ j.foodchem.2014.09.002

Ekasari, D., Suwetja, I., \& Montolalu, L. A. D.(2017). Uji Mutu Ikan Cakalang (Katsuwonus Pelamis-L) Dan Ikan Tongkol (Euthynnus Affinis) Segar Di Tpi Tumumpa Selama Penyimpanan Dingin. Jurnal Media Teknologi Hasil Perikanan, 5(2).

Erkan, N., Ozden, O., \& Selcuk, A. (2010). Effect of Frying, Grilling, and Steaming on Amino Acid Composition of Marine Fishes. Journal of Medical Food, 13(6), 1524-1531.

FAO (Food and Agriculture Organization of the United Nations). (2018). The State of World Fisheries and Aquaculture. FAO.

Hafiludin. (2011). Karakteristik proksimat dan kandungan senyawa kimia daging putih dan daging merah ikan tongkol (Euthynnus affinis). Jurnal Kelautan, 4(1).

Holma, Ayinsa, K., \& Maalekuu, B. K. (2013). Effect of traditional fish processing methods on the proximate composition of red fish stored under ambient room conditions. American Journal of Food And Nutrition, 15-24. https://doi.org/ 10.5251/ajfn.2013.3.2.73.82

Hosseini, N., \& Abdolmaleki, F. (2017). The Effects of Different Thawing Methods on the Hygienic Quality of the Canned Tuna. Journal of Food Biosciences and Technology, 7(2), 83-90.

Kim, Y., Nam, K., Park, S. Y., Kim, D. Y., Kang, S. I., Han, S., \& Kim, J. (2019). Nutritional Characteristics of the Major Commercial Frozen Seafood Products in Korea. The Korean Society of Fisheries and Aquatic Science, 52(1), 1-12.

Linder M.C. (2006). Biokimia Nutrisi dan Metabolisme terjemahan oleh Aminuddin Parakkasi. Penerbit UI Press. Jakarta.

Miao.H, Liu.Q, Bao.H, Wang, X., \& Miao, S. (2017). Eûects of diûerent freshness on the quality of cooked tuna steak. Innovative Food Science and Emerging Technologies, 44, 67-73.

Mohanty, B, Mahanty, A., \& Ganguly S. (2014). Amino Acid Compositions of 27 Food Fishes and Their Importance in Clinical Nutrition. Jurnal of Amino Acid. Hindawi Publishing Corporation. India.

Mugale, R., Patange, S. B., Joshi, V. R., Kulkarni, G. N., \& Shirdhankar, M. M. (2018). Textural and Sensory Characteristics of Eel Steaks Processed during Thermal Processing in Brine Medium to
Optimize F 0 Value. International Journal of Current Microbiology and Applied Sciences, 7(02), 849859.

Nurjanah, N., Suseno, S., Hidayat, T., Paramudhita, P. ., Ekawati, Y., \& Arifianto, T. . (2015). Changes in nutritional composition of skipjack (Katsuwonus pelamis ) due to frying process Changes in nutritional composition of skipjack ( Katsuwonus pelamis ) due to frying process. International Food Research Journal, 22(January).

Salum, P., Guclu, G., \& Selli, S. (2017). Comparative Evaluation of Key Aroma-Active Compounds in Raw and Cooked Red Mullet (Mullus barbatus) by Aroma Extract Dilution Analysis. Journal of Agricultural and Food Chemistry, 65. https:// doi.org/10.1021/acs.jafc.7b02756

Sediaoetama, A. D. (2000). Ilmu Gizi. Dian Rakyat. Jakarta.

Sotelo CG, Velasco A, Perez-Martin RI, Kappel K, Schro"der U, Verrez-Bagnis V,, Jerome, M,.. Mariani, S.(2018). Tuna labels matter in Europe/ : Mislabelling rates in different tuna products. PLOS ONE, 1-12.

Steiner-Asiedu, M., Asiedu, D., \& Njaa, L. (1991). Effect of Local Processing Methods ( Cooking , Frying and Smoking ) on Three Fish Species from Ghana/ : Part 2 Amino Acids and Protein Quality \& Leif Rein Njaa a. Food Chemistry, 41, 227-236.

Sundari D, Almasyhuri., \& Astuti L. (2015). Pengaruh Proses Pemasakan Terhadap Komposisi Zat Gizi Bahan Pangan Sumber Protein. Media Litbangkes, Vol. 25 No. 4. Kemenkes RI. Jakarta.

Suwetja. I.K. (2011). Biokimia Hasil Perikanan. Media Prima Aksara. Jakarta.

Winarno, FG. (2004). Kimia Pangan Dan Gizi. PT. Gramedia Pustaka Utama. Jakarta.

Yuliarti N. (2009). A to Z Food Supplement. CV. Andi Ofset. Yogyakarta.

Yunindra Y, Dewi A, Sullistya, Dina S, Venta dan Tri Amalia. (2014). Ikan Tuna Sebagai Sumber Protein. Fakultas Teknologi Pertanian Jurusan Teknologi Industri Pertanian Universitas Brawijaya. Malang.

Zhang, Y., Ma, X., \& Dai, Z. (2019). Comparison of nonvolatile and volatile compounds in raw, cooked, and canned yellowfin tuna ( Thunnus albacores ). Journal of Food Processing and Preservation, (April), 1-11. https://doi.org/ 10.1111/jfpp.14111. 